Louisiana State University

LSU Digital Commons

2-1-2018

\title{
Hemodynamics of the corpus luteum in mares during experimentally impaired luteogenesis and partial luteolysis
}

\author{
J. C. Ferreira \\ UNESP-Universidade Estadual Paulista \\ L. F.Novaes Filho \\ UNESP-Universidade Estadual Paulista \\ Y. L. Boakari \\ UNESP-Universidade Estadual Paulista \\ H. S. Canesin \\ UNESP-Universidade Estadual Paulista \\ D. L. Thompson \\ LSU Agricultural Center
}

See next page for additional authors

Follow this and additional works at: https://digitalcommons.Isu.edu/animalsciences_pubs

\section{Recommended Citation}

Ferreira, J., Filho, L., Boakari, Y., Canesin, H., Thompson, D., Lima, F., \& Meira, C. (2018). Hemodynamics of the corpus luteum in mares during experimentally impaired luteogenesis and partial luteolysis.

Theriogenology, 107, 78-84. https://doi.org/10.1016/j.theriogenology.2017.10.045

This Article is brought to you for free and open access by the School of Animal Sciences at LSU Digital Commons. It has been accepted for inclusion in Faculty Publications by an authorized administrator of LSU Digital Commons.

For more information, please contact ir@lsu.edu. 


\section{Authors}

J. C. Ferreira, L. F.Novaes Filho, Y. L. Boakari, H. S. Canesin, D. L. Thompson, F. S. Lima, and C. Meira 


\title{
Hemodynamics of the corpus luteum in mares during experimentally impaired luteogenesis and partial luteolysis
}

\author{
J.C. Ferreira a, b, *, L.F. Novaes Filho a , Y.L. Boakari a , H.S. Canesin ${ }^{\text {a }}$, D.L. Thompson Jr. ${ }^{\text {c }}$, \\ F.S. Lima ${ }^{\mathrm{b}}$, C. Meira ${ }^{\text {a }}$ \\ a Department of Animal Reproduction and Veterinary Radiology, School of Veterinary Medicine and Animal Science, UNESP, Botucatu, São Paulo, Brazil \\ ${ }^{\mathrm{b}}$ Department of Veterinary Clinical Medicine, College of Veterinary Medicine, University of Illinois, Champaign-Urbana, Illinois, United States \\ ' School of Animal Sciences, Louisiana State University Agricultural Center, Baton Rouge, LA, United States
}

\section{A R T I C L E I N F O}

\section{Article history:}

Received 23 May 2017

Received in revised form

25 October 2017

Accepted 30 October 2017

Available online 4 November 2017

\section{Keywords:}

Doppler ultrasonography

Progesterone

PGFM

Prolactin

Diestrus

\begin{abstract}
A B S T R A C T
The aim of the current project was to characterize the luteal vascularity and the plasma concentrations of progesterone (P4), prolactin (PRL) and 13,14-dihydro-15-keto-PGF $2 \alpha$ (PGFM) in mares with luteal disturbances during early and mid-diestrus. In Experiment 1, twenty-one mares were treated with $2 \mathrm{~mL}$ of $0.9 \% \mathrm{NaCl}$, or $1 \mathrm{mg}$ Dinoprost, or $10 \mathrm{mg}$ Dinoprost on day two after ovulation (Control-D2, 1/10PGF-D2 and PGF-D2 groups, respectively; $n=7$ mares/group). In Experiment 2, similar treatments were performed eight days post-ovulation using a different cohort of 21 mares (Control-D8, 1/10PGF-D8 and PGFD8 groups, respectively; $n=7$ mares/group). Blood samples were collected hourly and power-Doppler examinations of the corpus luteum (CL) were performed every $6 \mathrm{~h}$ from HO (moment immediately before treatment) to H48. Data collection was also done once a day from D0 (day of ovulation) to D20. In Experiment 1, the PGF-D2 and 1/10PGF-D2 groups had lower increase of plasma concentration of P4 until H48 and reduced maximum P4 concentrations on D8-D11 than mares from the Control-D2 group. However, no differences among groups were detected for luteal vascularity during early and middiestrus. In Experiment 2, complete and partial luteolysis were detected in mares from the PGF-D8 and 1/10PGF-D8 groups, respectively. Luteal vascularity and plasma P4 concentrations differed among Control-D8, PGF-D8 and 1/10PGF-D8 groups on H48. Partially regressed CLs (1/10PGF-D8 group) generated more Doppler signals than completed regressed CLs (PGF-D8 group) between D10 and D13. In both experiments, a transient increase in PRL activity was observed in parallel to the PGFM pulse in mares receiving 1 or $10 \mathrm{mg}$ Dinoprost. The use of prostaglandin on D2 at conventional or 1/10 of the dose impaired the luteal development in mares. Moreover, the low dose of prostaglandin lead to partial regression of mature CLs. The blood supply was reduced in partially regressed CLs, but not in CLs undergoing impaired luteogenesis.
\end{abstract}

Published by Elsevier Inc.

\section{Introduction}

The corpus luteum (CL) is a transient endocrine gland mainly responsible for the synthesis of progesterone (P4), which is required for the maintenance of normal pregnancy in mammals [1]. The cyclic lifespan of the CL is intimately sustained by a local angiogenic phenomenon [2]. In mares, luteogenesis requires a massive sprouting of blood vessels during the first three days after

\footnotetext{
* Corresponding author. Present address: College of Veterinary Medicine, $2001 \mathrm{~S}$ Lincoln Ave, Urbana, IL 61802, United States.

E-mail address: jaircamargoferreira@gmail.com (J.C. Ferreira).
}

ovulation [3,4]. Contrariwise, the regression of the CL is followed by a progressive degradation of its vasculature between days 13 and 16 of the estrus cycle [5].

Colored Doppler ultrasonography has become a readily accessible and valuable technology for reproductive management of females [6,7]. The close relationship between luteal vascularity and P4 levels during diestrus in mares [8-10] and cows [11,12] suggests the applicability of Doppler imaging for the analysis of luteal function. However, recent studies in bovine and equine species suggest that Doppler ultrasonography is not as accurate to determine luteal disturbances. The volume of bovine CL under partial regression changes significantly in parallel with the levels of P4, while the luteal vascularity remains unchanged [13]. Moreover, the 
vascularity of the mature $\mathrm{CL}$, but not the synthesis of progesterone, may be affected by the season in mares [14]. Finally, GnRH and hCG treatments can stimulate the vascular perfusion of the equine $\mathrm{CL}$ without affecting plasma progesterone concentrations [15]. Therefore, there is a critical need to accurately determine the applicability of Doppler ultrasonography as a real-time diagnostic instrument of luteal disorders.

Shortening the estrous cycle by inducing complete luteolysis with prostaglandin $\mathrm{F}_{2 \alpha}$ (PGF) or its analogues has been widely used in equine practice [16]. The effect of PGF on inducing complete regression of the mature $C L$ is dose-dependent $[17,18]$. Also, mares challenged with luteolytic agents during early diestrus undergo partial regression of the newly formed $\mathrm{CL}$ and subsequent resurgence of P4 [19,20]. Therefore, the use of PGF-based protocols may be useful as a model to investigate luteal disturbances during early and mid-diestrus in this species.

In mares and heifers [9,21], a greater pulsatility of the PGF metabolite 13,14-dihydro-15-keto-PGF2alpha (PGFM) occurred during luteolysis than during preluteolysis and postluteolysis. The presence of prolactin (PRL) receptors on the equine CL [22] indicates that PRL may directly affect ovarian steroidogenesis and the luteal structure through the diestrus. Also, the activity of PRL is markedly increased and synchronized with the PGFM pulses during complete luteolysis in mares [23]. Therefore, changes on PGF and PRL rhythmicity may be related to the impaired maturation and partial regression of the $C L$.

Since the inadequate levels of P4 may be a potential cause of infertility and early pregnancy loss in mares [24], the development of a rapid and on-site diagnostic method for compromised CLs is critical. Therefore, the main purpose of the present study was to characterize the endocrine profile and the CL blood-flow of mares with luteal disturbances during early and mid-diestrus. Our specific goals were: a) to describe the changes on plasma concentrations of P4, PGFM and PRL in mares with impaired luteogenesis or partial luteolysis, and b) to investigate the efficacy of color Doppler ultrasonography for the real-time diagnosis of luteal abnormalities.

\section{Material and methods}

\subsection{Animals and experimental groups}

A total of 42 cycling mixed breed mares were handled in accordance with the Guide for Care and Use of Agricultural Animals in Agricultural Research and Teaching. The mares were about 6-15 years of age, weighting $250-380 \mathrm{~kg}$. The animals maintained a high body condition score (score $\geq 7$ ) throughout the experiments [25]. The age of mares was estimated from dental characteristics [26]. The mares were kept under natural light in an open shelter and outdoor paddock during October-December at the Reproduction Center of the School of Veterinary Medicine and Animal Science, UNESP $\left(22^{\circ} 52^{\prime} 20^{\prime \prime} \mathrm{S}\right)$. All mares were maintained on grass hay, trace-mineralized salt and water ad libitum. In addition, pelleted feed was offered twice a day. No macroscopic abnormalities of the reproductive tract were detected by ultrasound examination. None of the mares had foaled during the last 5 years preceding the study.

B-mode ultrasonography examination was done once daily to monitor follicular development. Mares showing a pre-ovulatory follicle $\geq 35 \mathrm{~mm}$ of diameter and high endometrial edema [27] had ovulation induced intravenously with a single dose of 2500 IU of human chorionic gonadotrophin (hCG, Vetecor ${ }^{\circledR} 5000$ I.U., Calier S.A, Spain). Ultrasonography examination of the ovaries was performed every $6 \mathrm{~h}$ from hCG treatment until the observation of the CL [28]. Only mares with a single ovulation were used for this study. Day of ovulation was considered D0.

\subsubsection{Experiment 1: impact of prostaglandin challenges on the} development of the $C L$

Twenty-one mares were used to describe the effect of the luteolytic and sub-luteolytic doses of PGF on the luteal vascularity and the plasma concentrations of P4, PGFM and PRL during early diestrus. A single IM treatment of PGF (Dinoprost tromethamine; Lutalyse $^{\circledR}$, Zoetis Inc, Spain) was injected into the deep muscles of the neck on D2. The mares were arranged in three groups $(n=7$ mares/group) according to the PGF dose: $10 \mathrm{mg}$ PGF (luteolytic, $2 \mathrm{~mL}$ ), $1 \mathrm{mg}$ PGF (sub-luteolytic, $2 \mathrm{~mL}$ ) and $2 \mathrm{~mL}$ of $0.9 \% \mathrm{NaCl}$ (PGFD2, 1/10 PGF-D2 and Control-D2 groups, respectively).

\subsubsection{Experiment 2: effect of a low dose of prostaglandin on the maintenance of the mature $C L$}

The luteal vascularity and endocrine profile (P4, PGFM and PRL) of mares with partial or complete artificially induced or with spontaneous luteolysis were characterized using 21 additional mares. A single PGF treatment was done on D8 using the same doses described for Experiment 1. The mares were assigned into three groups ( $\mathrm{n}=7$ mares/group): PGF-D8, 1/10 PGF-D8 or ControlD8 groups.

\subsection{Data collection}

Blood samples were collected every hour and Doppler ultrasound examinations of the CL were performed every $6 \mathrm{~h}$ during the first $48 \mathrm{~h}$ after treatment. In both experiments, data was also collected once a day from D0 to D20. Daily data collection was performed between 1:00-2:00 p.m. The moment immediately before the treatment was considered HO.

\subsubsection{Doppler ultrasonography of the $C L$}

Mares were scanned per rectum using a pulse wavecolor Doppler ultrasound unit (Sonoace Pico; Medison do Brasil Ltda) equipped with a linear-array multifrequency transducer (LV59CDn, 5-9 MHz). The brightness and contrast controls of the monitor and the gain controls of the scanner were kept constant throughout the experiments [29]. Power-flow function was used to display blood flow signals in the luteal tissue as previously described in mares [15,31]. Vascularity of the CL was estimated subjectively by considering the percentage $(0 \%-100 \%)$ of luteal tissue with color Doppler signals during real-time imaging and continuous examination with a minimum of 1 -min scan. All Doppler ultrasonography examinations were performed at a constant color-gain setting and a velocity setting of $6 \mathrm{cms}^{-1}$. Luteal vascularity was estimated by one operator without knowledge of the treatment. The procedure for estimating the percentage of $\mathrm{CL}$ with blood-flow signals during early and mid-diestrus was previously validated in our laboratory [10].

\subsubsection{Blood samples and hormone assays}

Blood samples were collected by jugular venipuncture into heparinized tubes and immediately placed in ice-cold water for $10 \mathrm{~min}$. Subsequently, blood samples were centrifuged (2000g for $10 \mathrm{~min}$ at $\left.20^{\circ} \mathrm{C}\right)$, and plasma was stored $\left(-20^{\circ} \mathrm{C}, 2\right.$ cc cryotubes $)$ until assayed.

Solid-phase radioimmunoassay (RIA) for P4 and PRL was performed in the School of Animal Sciences at Louisiana State University Agricultural Center, Baton Rouge, USA. The plasma samples were assayed for PGFM by an enzyme-linked immunosorbent assay (ELISA) in the School of Veterinary Medicine and Animal Science, UNESP, Botucatu, Brazil.

Concentrations of plasma P4 were measured using a RIA kit containing antibody-coated tubes and ${ }^{125}$ I-labeled progesterone (Coat-a-count progesterone Kit, Diagnostic Product Corporation, 
DPC, Los Angeles, USA). The intra- and inter-assay CV and the assay sensitivity for P4 were $4.0 \%, 6.9 \%$, and $0.05 \mathrm{ng} \mathrm{mL}^{-1}$, respectively. Plasma samples were assessed for concentrations of prolactin with a previously validated RIA developed in our laboratory [30]. The intra- and inter-assay CV and the assay sensitivity for PRL were 7\%, $12 \%$, and $0.2 \mathrm{ng} \mathrm{mL}^{-1}$. Plasma PGFM concentrations were measured using the 13,14-dihydro-15 Prostaglandin $F_{2 \alpha}$ EIA kit (Cayman Chemical; Ann Arbor, USA). The PGFM intra- and inter-assay CV and the sensitivity for PGF assay were $7.8 \%, 9.0 \%$, and $28.3 \mathrm{pg} \mathrm{mL}^{-1}$, respectively.

Mares with plasma P4 concentrations $<2 \mathrm{ng} \mathrm{mL}^{-1}$ within $48 \mathrm{~h}$ after treatment were considered to have had complete regression of the CL [21]. In experiment 1, impaired luteogenesis was indicated by a low rate of increase in $\mathrm{P} 4$ concentrations on $\mathrm{H} 0-\mathrm{H} 48$ when compared to Control-D2 group. In experiment 2, partial luteolysis was characterized by a progressive decrease of the P4 levels without reaching plasma concentrations $<2 \mathrm{ng} \mathrm{mL}^{-1}$ on $\mathrm{H} 48$ [18].

\subsection{Statistical analyses}

The continuous data (luteal vascularity, plasma P4, PGFM and PRL) with repeated measures over time within an experimental unit were analyzed using the MIXED procedure of SAS (SAS/STAT version 9.3; SAS Institute Inc., Cary, NC) with models fitting a Gaussian distribution. Data were tested for normality of residuals, and non-normally distributed data were transformed before analysis if improvement in residual distribution was observed. To determine the main effects and interactions, a repeated statement was used to account for autocorrelation between sequential measurements. Post hoc analyses were conducted using Tukey test. The level of significance was defined at 0.05 . Data are presented as the mean \pm standard error of the mean (SEM).

\section{Results}

\subsection{Experiment 1}

A negative effect of prostaglandin on plasma $\mathrm{P} 4$ concentrations was observed during the first $48 \mathrm{~h}$ after treatment on $\mathrm{D} 2(\mathrm{P}<0.001$; Fig. 1). P4 progressively increased in the Control-D2 group starting at $\mathrm{H} 2(\mathrm{P}<0.001)$, while no changes were detected in the $1 / 10 \mathrm{PGF}-$ $\mathrm{D} 2$ and PGF-D2 mares until $\mathrm{H} 16$ and $\mathrm{H} 39$, respectively $(\mathrm{P}>0.2)$. In addition, the 1/10PGF-D2 and PGF-D2 groups had lower levels of P4 $(\mathrm{P}<0.05)$ than Control-D2 group, respectively, on H35-H48 and H5-H48. Mares from the 1/10PGF-D2 and PGF-D2 groups had similarly low levels of $\mathrm{P} 4$ on $\mathrm{H} 48\left(9.0 \pm 0.5 \mathrm{ng} \mathrm{mL}^{-1}\right.$ and $6.3 \pm 1.2 \mathrm{ng} \mathrm{mL}^{-1}$, respectively; $\mathrm{P}>0.3$ ) when compared to Control$\mathrm{D} 2$ group $\left(14.2 \pm 0.8 \mathrm{ng} \mathrm{mL}^{-1} ; \mathrm{P}<0.05\right)$.

Effect of treatment, day and their interaction $(P<0.001)$ was detected for plasma P4 concentration from D0 to D20 (Fig. 2). When compared to the Control-D2 group, the PGF-D2 and 1/10PGF-D2 groups had lower $(\mathrm{P}<0.001)$ levels of $\mathrm{P} 4$ on D3-D10 and D7-D10, respectively. Statistical differences between the PGF-D2 and 1/ 10PGF-D2 groups for P4 concentrations within a day were detected from D3 to D5 $(\mathrm{P}<0.001)$. Also, the maximum plasma P4 concentration was similarly lower in the 1/10PGF-D2 and PGF-D2 groups $\left(11.1 \pm 0.6\right.$ and $10.3 \pm 0.4 \mathrm{ng} \mathrm{mL}^{-1}$, respectively; $\left.\mathrm{P}>0.3\right)$ than in the Control-D2 group $\left(17.1 \pm 0.2 \mathrm{ng} \mathrm{mL}^{-1} ; \mathrm{P}<0.05\right)$. In opposite to the observed during the first hours after treatment, the PGF-D2 and 1/10PGF-D2 groups had greater $(\mathrm{P}<0.05)$ levels of P4 than Control-D2 mares on D14-D16 (Fig. 2). The complete luteolysis $\left(\mathrm{P} 4<2.0 \mathrm{ng} \mathrm{mL}^{-1}\right)$ occurred at $14.8 \pm 0.5,16.5 \pm 0.3$ and $16.6 \pm 0.9$ days after ovulation in the Control-D2, 1/10PGF-D2 and PGF-D2 groups, respectively.

No differences $(P>0.3)$ between groups related to vascularity
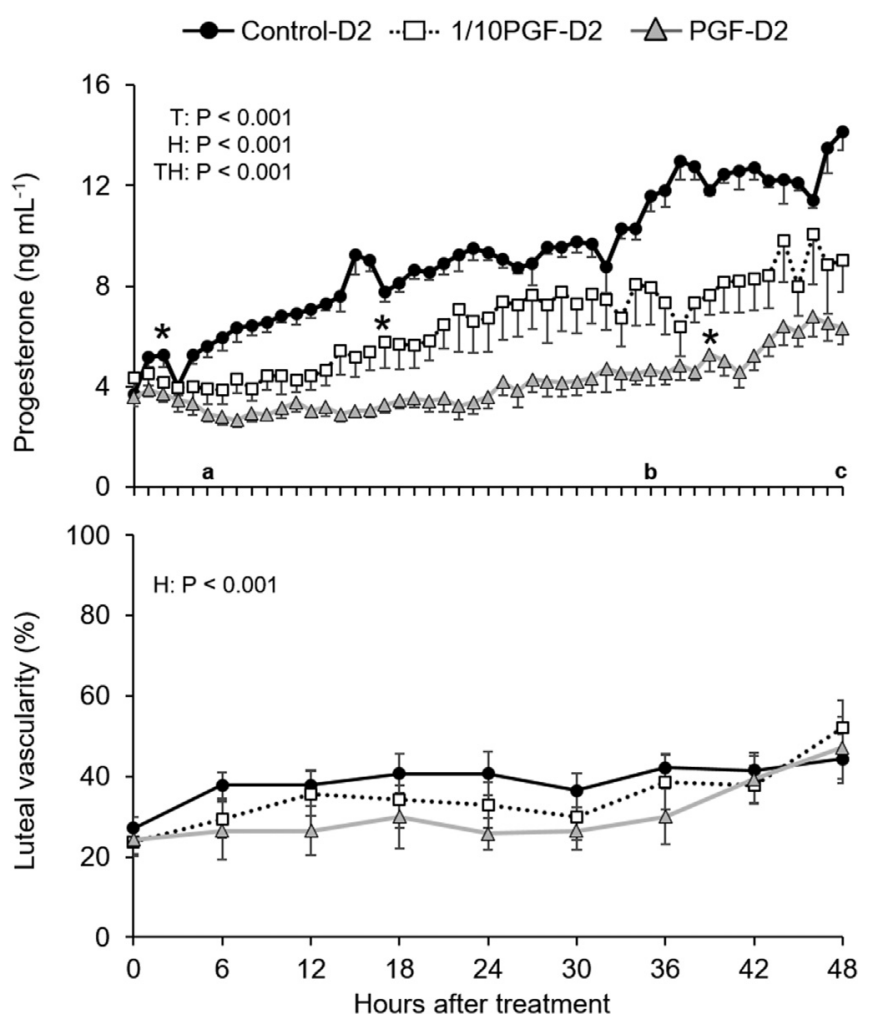

Fig. 1. Mean $( \pm \mathrm{SEM})$ for plasma progesterone concentration $\left(\mathrm{ng} \mathrm{mL}^{-1}\right)$ and luteal vascularity (\%) in mares during the first $48 \mathrm{~h}$ after treatment on D2. The main effect of treatment $(\mathrm{T})$, hour $(\mathrm{H})$ and the interaction $(\mathrm{T}: \mathrm{H})$ are shown. $\mathrm{H} 0=$ moment immediately before treatment. * First detected increase $(P<0.05)$ within each group. ${ }^{\mathrm{a}-\mathrm{c}}$ Indicates the interval in which the PGF-D2 and Control-D2 groups were different $(P<0.05) .{ }^{\mathrm{b}-\mathrm{c}}$ Indicates the interval in which the $1 / 10 \mathrm{PGF}-\mathrm{D} 2$ and Control-D2 groups were different $(P<0.05)$.

were found within time during the first $48 \mathrm{~h}$ after treatment (Fig. 1 and Table 1). Independent of the treatment, luteal vascularity increased from D0 to D6 (P > 0.001; Fig. 2). Similar to the observed for plasma P4 concentrations during late diestrus, the luteal vascularity decreased first $(\mathrm{P}<0.001)$ in the Control-D2 group than in mares from the PGF-D2 and 1/10PGF-D2 groups (Fig. 2). Mares treated with prostaglandin on D2 showed greater luteal vascularity than mares from the Control-D2 group between D14 and D16 $(\mathrm{P}<0.05)$.

A transitory increase $(\mathrm{P}<0.001)$ of PGFM was detected immediately after treatment in the PGF-D2 and 1/10PGF-D2 groups (Fig. 3). Plasma PGFM concentrations were statistically different among the three groups on H1-H2. Similarly, PGF-D2 mares had greater levels of PRL than the 1/10GDF-D2 and Control-D2 groups during the first $3 \mathrm{~h}$ after treatment $(P<0.003)$. No differences $(\mathrm{P}>0.1)$ between 1/10GDF-D2 and Control-D2 were found for PRL during the experiment (Fig. 3 ).

\subsection{Experiment 2}

Effect of treatment, hour and their interaction $(\mathrm{P}<0.001)$ was detected for plasma $\mathrm{P} 4$ concentrations in mares receiving 1 or $10 \mathrm{mg}$ Dinoprost on D8 (Fig. 4). P4 was constantly high in the Control-D8 group from H0 to H48 $\left(14.5 \pm 0.2 \mathrm{ng} \mathrm{mL}^{-1} ; \mathrm{P}>0.3\right)$. Decreased levels of $\mathrm{P} 4$ were first detected $(\mathrm{P}<0.0001)$ on $\mathrm{H} 2$ and H6 in the PGF-D8 and 1/10PGF-D8 groups, respectively. Also, the 1/ 10PGF-D8 group showed constantly greater $(\mathrm{P}<0.001)$ levels of $\mathrm{P} 4$ than the PGF-D8 group from $\mathrm{H} 27$ to $\mathrm{H} 48$. At the end of the first $48 \mathrm{~h}$ after treatment (Table 2), plasma P4 concentrations 

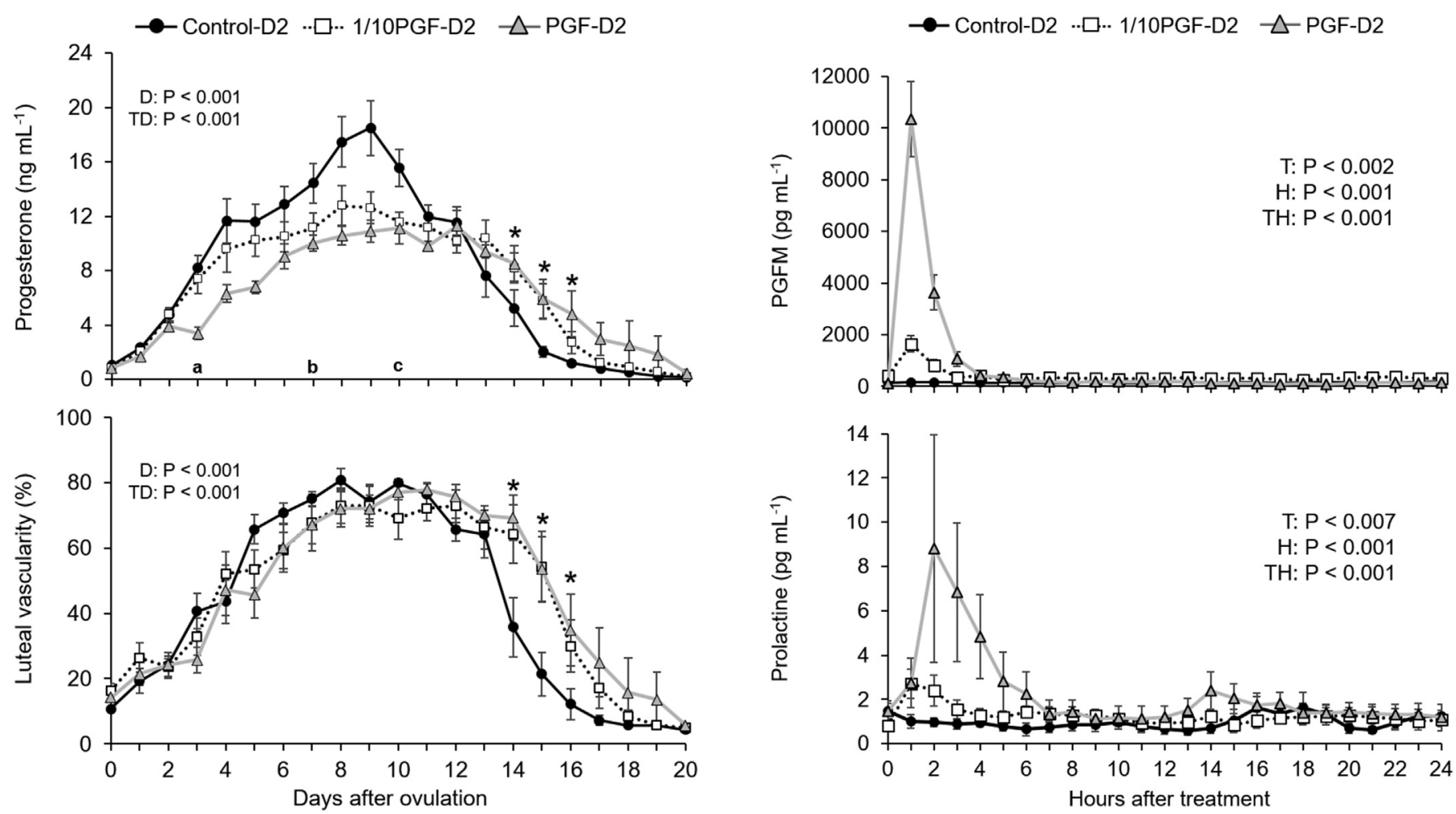

Fig. 2. Mean $( \pm \mathrm{SEM})$ for plasma progesterone concentration $\left(\mathrm{ng} \mathrm{mL}^{-1}\right)$ and luteal vascularity (\%) from D0 to D20 of mares treated on D2. The main effect of day (D) and the interaction day:treatment (T:D) are shown. ${ }^{\mathrm{a}-\mathrm{c}}$ Indicates the interval in which the PGF-D2 and Control-D2 groups were different $(P<0.05)$. ${ }^{\mathrm{b}-\mathrm{c}}$ Indicates the interval in which the $1 / 10 \mathrm{PGF}-\mathrm{D} 2$ and Control-D2 groups were different $(P<0.05) .{ }^{*}$ Control-D2 group was different $(\mathrm{P}<0.05)$ than PGF-D2 and 1/10PGF-D2 groups within the same hour.

remained $>2 \mathrm{ng} \mathrm{mL}^{-1}$ in the Control-D8 and 1/10PGF-D8 groups $\left(16.0 \pm 1.3\right.$ and $4.6 \pm 1.1 \mathrm{ng} \mathrm{mL}^{-1}$, respectively), but not in the PGFD8 group $\left(1.3 \pm 0.2 \mathrm{ng} \mathrm{mL}^{-1}\right)$.

When compared to the Control-D8 group, mares treated with 1 or $10 \mathrm{mg}$ Dinoprost on D8 had reduced P4 between D9 and D14 $(\mathrm{P}<0.01$; Fig. 5). Concentrations of $\mathrm{P} 4$ also differed $(\mathrm{P}<0.04)$ between the 1/10PGF-D8 and PGF-D8 groups on D10-D13. The day of complete $\mathrm{CL}$ regression ( $\mathrm{P} 4<2.0 \mathrm{ng} \mathrm{mL}^{-1}$ ) was statistically different $(\mathrm{P}<0.05)$ among the PGF-D8, 1/10PGF-D8 and Control-D8 groups $(9.7 \pm 0.2,13.6 \pm 0.8$ and $15.6 \pm 0.5$ days after ovulation, respectively).

The luteal vascularity was constantly high $(79.0 \pm 2.1 \% ; \mathrm{P}>0.2)$ in the Control-D8 group between H0 and H48 (Fig. 4). Decreased

\section{Table 1}

Mean $\left({ }_{ \pm} \mathrm{SEM}\right)$ for plasma progesterone concentrations $\left(\mathrm{ng} \mathrm{mL}^{-1}\right)$ and luteal vascularity (\%) of mares treated with $2 \mathrm{~mL} \mathrm{NaCl} 0.9 \%, 1 \mathrm{mg}$ Dinoprost tromethamine or $10 \mathrm{mg}$ Dinoprost tromethamine on D2 (Control-D2, 1/10PGF-D2 and PGF-D2 groups, respectively).

\begin{tabular}{lccccc}
\hline \multirow{2}{*}{ Groups } & \multicolumn{2}{c}{ Progesterone } & & \multicolumn{2}{c}{ Luteal vascularity } \\
\cline { 2 - 3 } \cline { 5 - 6 } & $\mathrm{HO}^{\mathrm{d}}$ & $\mathrm{H}^{\mathrm{a}} 8^{\mathrm{e}}$ & & $\mathrm{HO}^{\mathrm{d}}$ & $\mathrm{H}^{\mathrm{e}} 8^{\mathrm{e}}$ \\
\hline Control-D2 & $3.7 \pm 0.0^{\mathrm{aA}}$ & $14.2 \pm 0.8^{\mathrm{aB}}$ & & $27.1 \pm 2.6^{\mathrm{aC}}$ & $44.3 \pm 6.1^{\mathrm{aD}}$ \\
1/10PGF-D2 & $4.3 \pm 0.0^{\mathrm{aA}}$ & $9.0 \pm 0.5^{\mathrm{bB}}$ & & $23.6 \pm 3.4^{\mathrm{aC}}$ & $52.1 \pm 6.7^{\mathrm{aD}}$ \\
PGF-D2 & $3.6 \pm 0.0^{\mathrm{aA}}$ & $6.3 \pm 1.2^{\mathrm{cB}}$ & & $24.2 \pm 3.7^{\mathrm{aC}}$ & $47.1 \pm 7.8^{\mathrm{aD}}$ \\
\hline
\end{tabular}

a, b, cProgesterone means or luteal vascularity means with different letters within an same hour are different.

A, B Progesterone means with different letters within a group are different.

C, D Luteal vascularity means with different letters within a group are different.

d Moment immediately before the treatment.

e Hour 48 after treatment.

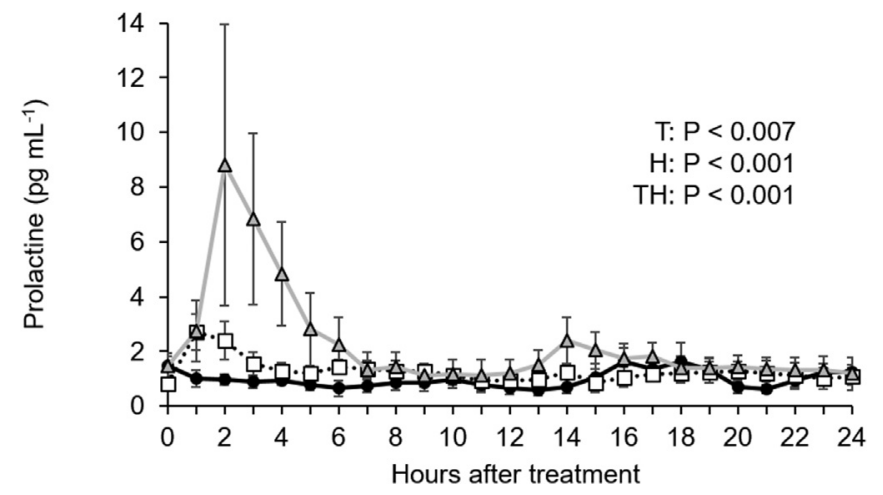

Fig. 3. Mean $\left({ }_{ \pm} \mathrm{SEM}\right)$ for plasma concentrations of PGFM and Prolactin $\left(\mathrm{pg} \mathrm{mL}{ }^{-1}\right)$ in mares during the first $24 \mathrm{~h}$ after treatment on D2. The main effect of treatment (T), hour $(\mathrm{H})$ and the interaction $(\mathrm{T}: \mathrm{H})$ are shown. $\mathrm{HO}=$ moment immediately before treatment.

values of luteal vascularity were first detected $24 \mathrm{~h}$ after treatment in the PGF-D8 and 1/10PGF-D8 ( $\mathrm{P}<0.001$; Fig. 4). Moreover, the vascularity of the $\mathrm{CL}$ differed among the three groups on $\mathrm{H} 48$ $(\mathrm{P}<0.05$; Table 2$)$. Considering the daily examinations, mares from the $1 / 10$ PGF-D8 group also had greater $(\mathrm{P}<0.05)$ luteal vascularity than the PGF-D8 group until D13 (Fig. 5).

A transitory increase $(P<0.005)$ of PGFM was detected immediately after the treatment in the PGF-D8 and 1/10PGF-D8 groups (Fig. 6). Plasma PGFM concentrations were higher in the PGF-D8 group than in the Control-D8 and 1/10PGF-D8 between $\mathrm{H} 1$ and $\mathrm{H} 4(\mathrm{P}<0.02)$. When compared to the Control-D8 group, mares from the PGF-D8 and 1/10PGF-D8 groups had greater PRL levels $(\mathrm{P}<0.05)$ on $\mathrm{H} 2-\mathrm{H} 5$ and $\mathrm{H} 1-\mathrm{H} 2$, respectively (Fig. 6). In addition, PRL differed between the PGF-D8 and 1/10PGF-D8 groups on $\mathrm{H} 2$ H5 $(\mathrm{P}<0.004)$.

\section{Discussion}

The present study was the first to characterize the hemodynamics of equine CLs with compromised development and incomplete luteolysis. The use of luteolytic and sub-luteolytic doses of PGF on D2 of the estrous cycle impaired luteogenesis in mares, whereas the low dose of PGF induced partial regression of the mature CL without a rebound effect of P4.

It was a long-standing belief that the equine CL should be fully formed before responding to a luteolytic therapy [31]. However, the potential refractoriness of the developing CL has been reconsidered since a delayed increase or a transient decrease of P4 were associated with PGF usage during the periovulatory period in mares $[19,20,32]$. The early developing CL appears to be responsive to exogenous PGF as early as within the first $24 \mathrm{~h}$ after ovulation 


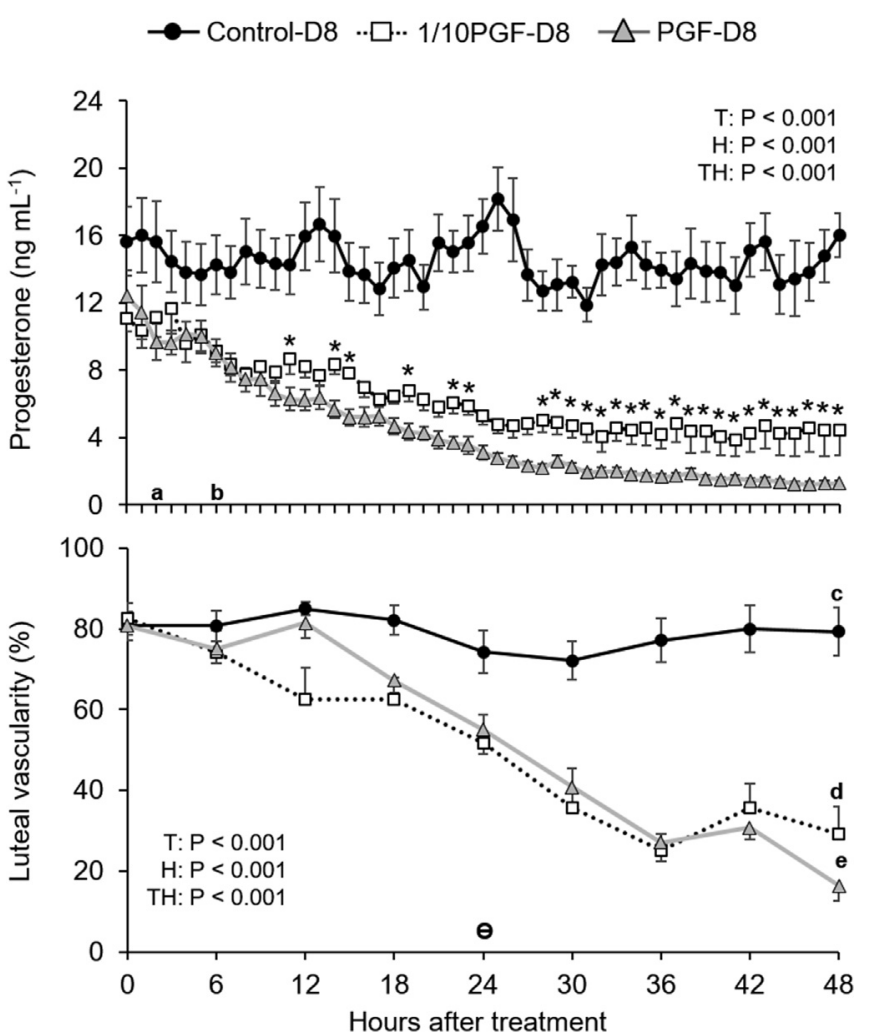

Fig. 4. Mean $\left({ }_{ \pm} \mathrm{SEM}\right)$ for plasma progesterone concentration $\left(\mathrm{ng} \mathrm{mL}^{-1}\right)$ and luteal vascularity (\%) in mares during the first $48 \mathrm{~h}$ after treatment on D8. The main effect of treatment $(\mathrm{T})$, hour $(\mathrm{H})$ and the interaction $(\mathrm{T}: \mathrm{H})$ are shown. $\mathrm{HO}=$ moment immediately before treatment. ${ }^{\mathrm{a}, \mathrm{b}}$ First detected decrease $(P<0.05)$ within the PGF-D8 and $1 /$ 10PGF-D8 groups, respectively. ${ }^{*}$ PGF-D8 and 1/10PGF-D8 groups were different $(\mathrm{P}<0.05)$ within the same hour. ${ }^{\ominus}$ First detected decrease $(P<0.05)$ within the PGF-D8 and 1/10PGF-D8 groups. c, d, e Control-D8, PGF-D8 and 1/10PGF-D8 groups were different $(P<0.05)$ within the same hour.

[33,34]. Moreover, the repeated administration of PGF over early diestrus induces a complete antiluteogenic outcome in this species [35]. In fact, our findings demonstrated that even a single microdose PGF treatment (1 mg Dinoprost) led to a reduced raise in plasma P4 concentration throughout the second day after ovulation, while mares receiving the labeled PGF dosage (10 mg Dinoprost) had a prolonged delay in the release of $\mathrm{P} 4$ during the luteogenesis.

Compromised CLs due to PGF-based treatments during the first days after ovulation seemed to rebound to normality by D7-D9 $[20,36]$. Surprisingly, a succeeding raise of P4 to similar levels seen

\section{Table 2}

Mean $\left({ }_{ \pm} \mathrm{SEM}\right)$ for plasma progesterone concentrations $\left(\mathrm{ng} \mathrm{mL}^{-1}\right)$ and luteal vascularity (\%) of mares treated with $2 \mathrm{~mL} \mathrm{NaCl} 0.9 \%, 1 \mathrm{mg}$ Dinoprost tromethamine or $10 \mathrm{mg}$ Dinoprost tromethamine on D8 (Control-D8, 1/10PGF-D8 and PGF-D8 groups, respectively).

\begin{tabular}{lcclll}
\hline \multirow{2}{*}{ Groups } & \multicolumn{2}{c}{ Progesterone } & & \multicolumn{2}{c}{ Luteal vascularity } \\
\cline { 2 - 3 } \cline { 5 - 6 } & $\mathrm{H}^{\mathrm{e}}$ & $\mathrm{H} 48^{\mathrm{f}}$ & & $\mathrm{H}^{\mathrm{e}}$ & $\mathrm{H}^{\mathrm{e}}$ \\
\hline Control-D8 & $15.7 \pm 2.8^{\mathrm{fA}}$ & $16.1 \pm 1.3^{\mathrm{aA}}$ & & $80.7 \pm 3.5^{\mathrm{aC}}$ & $79.3 \pm 6.0^{\mathrm{aC}}$ \\
1/10PGF-D8 & $11.1 \pm 0.8^{\mathrm{aA}}$ & $4.4 \pm 1.5^{\mathrm{bB}}$ & & $82.5 \pm 3.7^{\mathrm{aC}}$ & $29.2 \pm 6.9^{\mathrm{bD}}$ \\
PGF-D8 & $12.4 \pm 1.5^{\mathrm{aA}}$ & $1.3 \pm 0.2^{\mathrm{cB}}$ & & $80.7 \pm 2.3^{\mathrm{aC}}$ & $16.4 \pm 3.9^{\mathrm{cD}}$ \\
\hline
\end{tabular}

a, b, c Progesterone means or luteal vascularity means with different letters within an same hour are different.

A, B Progesterone means with different letters within a group are different.

C, D Luteal vascularity means with different letters within a group are different.

e Moment immediately before the treatment.

${ }^{\mathrm{f}}$ Hour 48 after treatment.
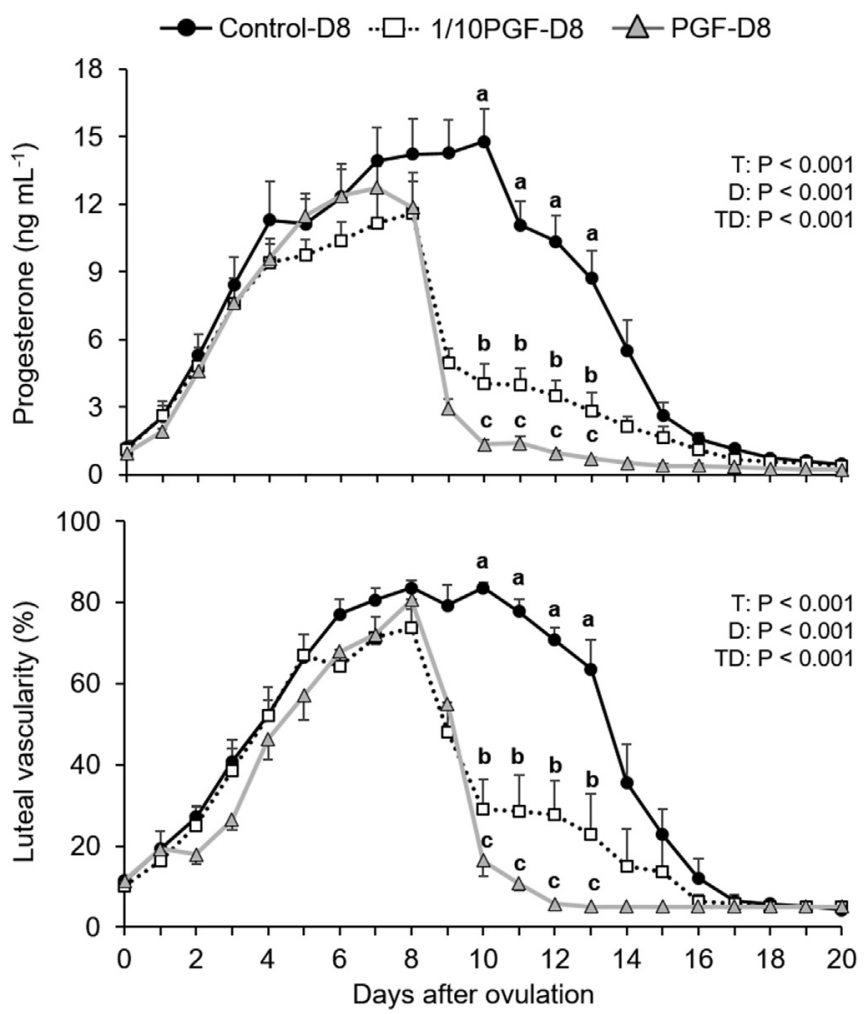

Fig. 5. Mean $\left( \pm\right.$ SEM) for plasma progesterone concentration $\left(n g \mathrm{~mL}^{-1}\right)$ and lutea vascularity (\%) from D0 to D20 of mares treated on D8. The main effect of treatment (T) day (D) and the interaction (T:D) are shown. D0 = day of ovulation. Experiment 2. ${ }^{\mathrm{a}, \mathrm{b}} \mathrm{c}$ Control-D8, PGF-D8 and 1/10PGF-D8 groups were different $(P<0.05)$ within the same hour.
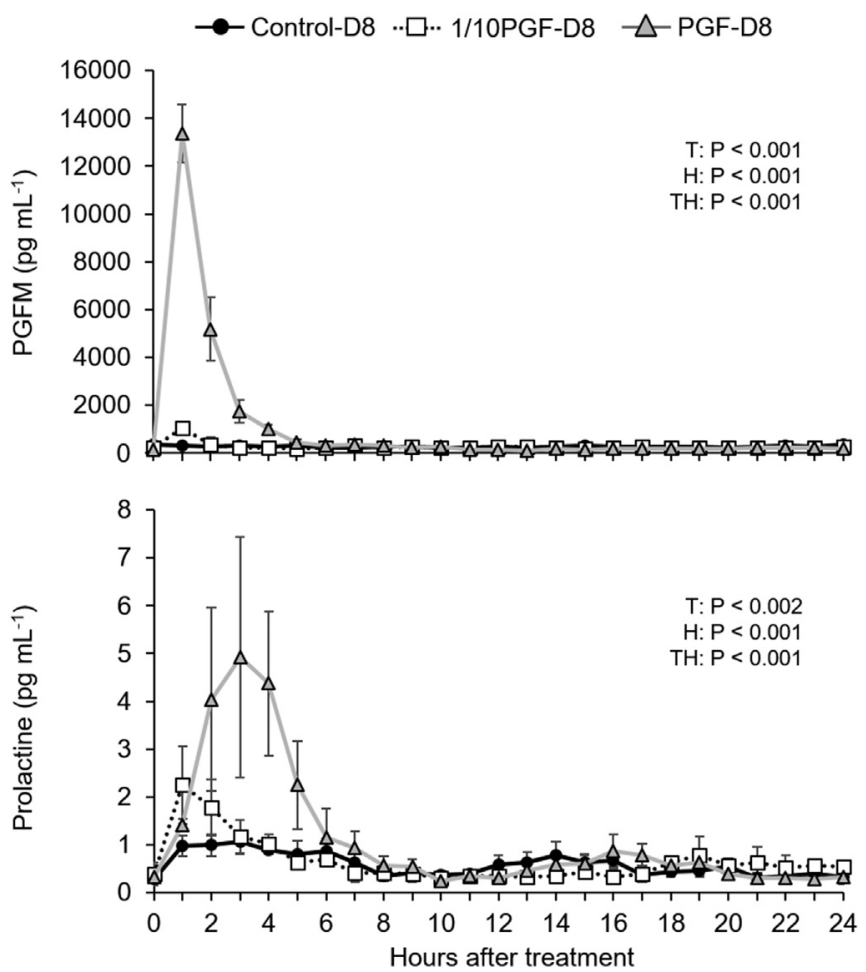

Fig. 6. Mean $\left( \pm\right.$ SEM) for plasma concentrations of PGFM and Prolactin $\left(\mathrm{pg} \mathrm{mL}^{-1}\right)$ in mares during the first $24 \mathrm{~h}$ after treatment on D8. The main effect of treatment (T) hour $(\mathrm{H})$ and the interaction $(\mathrm{T}: \mathrm{H})$ are shown. $\mathrm{HO}=$ moment immediately before treatment. 
in the control group was not observed in the mares with altered luteogenesis from Experiment 1 . The reduced maximum production of P4 observed in the PGF-D2 and 1/10PGF-D2 mares suggests a long-lasting impact of exogenous PGF on the luteal function. Even though the deficiency of P4 may be a concern for early embryonic development [37], pregnancy rates in mares are apparently unaffected by the administration of luteolytic agents during the periovulatory period $[36,38]$. Also, it is important to note that the P4 levels of both groups that received PGF on D2 remained considerably higher than the minimal needed for pregnancy maintenance [8].

The initial decrease in P4 followed by continuous values > $2 \mathrm{ng} \mathrm{mL} \mathrm{mL}^{-1}$ until late diestrus showed that a single administration of $1 \mathrm{mg}$ Dinoprost was effective to induce the incomplete regression of midcycle CLs (1/10PGF-D8 group; Experiment 2). Our findings are supported by studies in dairy and beef cows $[13,39,40]$, which also describe a limited effect of subluteolytic doses of PGF in the CL function. However, in contrast to the observed in cattle [41], the resurgence of partially regressed CLs was not detected in mares receiving micro-doses of PGF during mid-diestrus.

The temporal relationship between plasma PRL concentrations and PGFM pulses throughout late diestrus is well documented in mares $[23,42]$. Nevertheless, this was the first report of the doseeffect of exogenous PGF on the PRL profile in mares with newly formed and midcycle CLs. Independent of the estrous stage, the synchronic pulses of PGFM and PRL detected immediately after PGF-treatment were followed by nadir values until $\mathrm{H} 24$. Our results confirmed that the increase of plasma PRL concentrations is a primary effect of PGF and not a result of the variations on P4 production, as previously suggested in mares [42] and cows [43-45]. Apparently, the PRL activity is more likely to have a role in follicular maturation than in luteolysis $[46,47]$. The inability to duplicate sequential pulses of PGFM and PRL reported throughout the spontaneous luteolysis [23] was a limitation of the current approach (a single bolus injection of PGF). Nevertheless, our results encourage further studies with refined experimental designs aiming to simulate the endogenous deliver of PGF associated with luteal abnormalities.

The equine $\mathrm{CL}$ model has a considerable potential for Doppler studies due to its large dimensions, extensive vascularity and high PGF sensitivity [7]. However, the subjective analysis of the CL blood-flow (luteal vascularity) was not sufficient to identify mares with reduced raise in plasma $\mathrm{P} 4$ concentration during early diestrus (PGF-D2 and 1/10PGF-D2 groups; Experiment 1). The similar luteal vascularity between mares with normal and delayed luteogenesis suggests that the development and maintenance of the intraluteal vessels was not affected by a single PGF treatment on D2. Interestingly, the administration of $10 \mathrm{mg}$ Dinoprost on day three after ovulation has induced a significant structural regression of the equine CL [19]. In that case, however, the exogenous PGF also triggered an abrupt decrease in $\mathrm{P} 4$ concentrations to nadir values, a phenomenon not observed in the present study. These distinct luteolytic effects of $10 \mathrm{mg}$ Dinoprost are related to the age of the CL at the moment of experimental PGF treatment. The $6 \mathrm{~h}$ interval between the ultrasonography examinations of the ovaries after hCG treatment assured the earlier detection of the CL. Therefore, all mares from Experiment 1 received exogenous PGF between 48 and $54 \mathrm{~h}$ after ovulation. In the previous study [16], examinations to detect the ovulation were performed at approximately $24 \mathrm{~h}$ intervals and, consequently, the PGF treatments were done 72-96 h after the first visualization of the CL.

Doppler ultrasonography was effective for diagnosing functional disturbances of midcycle CLs (1/10PGF-D8 group; Experiment 2). In contrast to the described in heifers [12], an increase in luteal vascularity during the ascending portion of the PGFM pulse did not occur in mares receiving 10 or $1 \mathrm{mg}$ Dinoprost on D8. However, the vascularity of completely regressed CLs reached nadir values within the first $48 \mathrm{~h}$ after treatment, while partially regressed CLs still generated greater amount of color signals until late diestrus. The beginning of the complete and partial regression of the mature $\mathrm{CL}$, as indicated by the decrease in P4 concentrations [31], was initiated well before the beginning of the decrease in luteal vascularity. Despite the functional cross-talk between steroidogenic and vascular cells of the CL $[12,48]$, the slower decrease in luteal vascularity than in $\mathrm{P} 4$ concentrations is compatible with the results of previous studies of spontaneous and induced luteolysis [8,9,49].

The absence of blood-flow oscillations following PGF challenges during early diestrus (Experiment 1 ) and the distinct vascularity between partially and completely regressed CLs (Experiment 2) indicate that the luteal vascular changes were stage and PGF-dose dependent, as previously suggested in cows [50]. Several different mechanisms are potentially involved in the microvasculature remodeling of completely and partially regressed CLs. The reduced luteal blood supply in response to PGF has been associated with changes in the arterial wall resistance of the ovary [51]. PGF not only induces the local release of several vasoconstrictor agents $[52,53]$, but also modulates the expression of vasodilatory and proangiogenic substances [54-56].

\section{Conclusion}

Independent the dosage, a single PGF treatment on day two after ovulation reduced the raise in plasma concentration and the maximum production of P4 during diestrus. Experimental partially regressed CLs did not rebounded to normality. Power-Doppler ultrasonography failed to diagnose impaired luteogenesis, but was effective for the real-time identification of incomplete luteolysis during mid-diestrus. The immediate and transient increase of PRL was a primary effect of PGF and not a result of the reduced production of P4. Further studies will be needed to clarify the mechanisms that underlie the partial refractoriness of newly formed CLs and the specific signaling pathways associated with luteal disturbances in mares.

\section{Acknowledgments}

This research was financially supported by FAPESP, SP, Brazil (protocol numbers \# 1070/2012; 2012/122868-6).

\section{References}

[1] Niswender GD, Juengel JL, Silva PJ, Rollyson MK, McIntush EW. Mechanisms controlling the function and life span of the corpus luteum. Physiol Rev 2000;80:1-29.

[2] Acosta TJ, Miyamoto A. Vascular control of ovarian function: ovulation, corpus luteum formation and regression. Anim Reprod Sci 2004;82:127-40.

[3] Watson E, Fraser H. Angiogenesis and vascular endothelial growth factor expression in the equine corpus luteum. Reproduction 2003;125:259-70.

[4] Bergfetl DR, Adams GP. Ovulation and corpus luteum development. In: Pycock J, Samper JC, McKinnon AO, editors. Current therapy in equine reproduction. St. Louis: Saunders Elsevier; 2007. p. 1-13.

[5] Ginther O. Reproductive biology of the mare: basic and applied aspects. Cross Plains: Equiservices Publishing; 1992.

[6] Ginther O. How ultrasound technologies have expanded and revolutionized research in reproduction in large animals. Theriogenology 2014;81:112-25.

[7] Ginther O. Ultrasonic imaging and animal reproduction: color-Doppler ultrasonography, book 4. Cross Plains: Equiservices Publishing; 2007.

[8] Ginther O, Gastal E, Gastal M, Utt M, Beg M. Luteal blood flow and progesterone production in mares. Anim Reprod Sci 2007;99:213-20.

[9] Ginther O, Rodrigues B, Ferreira J, Araujo R, Beg M. Characterisation of pulses of 13, 14-dihydro-15-keto-PGF2alpha (PGFM) and relationships between PGFM pulses and luteal blood flow before, during, and after luteolysis in mares. Reprod Fertil Dev 2008;20:684-93.

[10] Romano RM, Ferreira JC, de Siqueira Canesin H, Boakari YL, Ignácio FS, Novaes 
Filho LF, et al. Characterization of luteal blood flow and secretion of progesterone in mares treated with human chorionic gonadotropin for ovulation induction or during early diestrus. J Equine Vet S. C 2015;35:591-7.

[11] Acosta TJ, Hayashi K, Ohtani M, Miyamoto A. Local changes in blood flow within the preovulatory follicle wall and early corpus luteum in cows. Reproduction 2003;125:759-67.

[12] Acosta TJ, Yoshizawa N, Ohtani M, Miyamoto A. Local changes in blood flow within the early and midcycle corpus luteum after prostaglandin F2 $\alpha$ injection in the cow. Biol Reprod 2002;66:651-8.

[13] Trevisol E, Ferreira JC, Ackermann CL, Destro FC, Marques Filho WC, Carmagos AS, et al. Luteal changes after treatment with sub-luteolytic doses of prostaglandin (cloprostenol sodium) in cattle. Anim Reprod Sci 2015;153: $8-12$.

[14] Panzani D, Di Vita M, Lainé A-L, Guillaume D, Rota A, Tesi M, et al. Corpus luteum vascularization and progesterone production in autumn and winter cycles of the mare: relationship between ultrasonographic characteristics of corpora lutea and plasma progesterone concentration in the last cycles before anestrus. J Equine Vet Sci 2017;56:35-9.

[15] Brito L, Baldrighi J, Wolf C, Ginther O. Effect of GnRH and hCG on progesterone concentration and ovarian and luteal blood flow in diestrous mares. Anim Reprod Sci 2017;176:64-9.

[16] Bradecamp EA. Estrous synchronization. In: Pycock J, Samper JC, McKinnon AO, editors. Current therapy in equine reproduction. St. Louis: Saunders Elsevier; 2007. p. 22-5.

[17] Cuervo-Arango J, Newcombe J. Relationship between dose of cloprostenol and age of corpus luteum on the luteolytic response of early dioestrous mares: a field study. Reprod Domest Anim 2012;47:660-5.

[18] Irvine C, McKeough VL, Turner J, Alexander S, Taylor T. Effectiveness of a twodose regimen of prostaglandin administration in inducing luteolysis without adverse side effects in mares. Equine Vet J 2002;34:191-4.

[19] Bergfelt D, Pierson R, Ginther O. Regression and resurgence of the CL following PGF $2 \alpha$ treatment 3 days after ovulation in mares. Theriogenology 2006;65: 1605-19.

[20] Nie GJ, Johnson KE, Wenzel JG, Braden TD. Luteal function in mares following administration of oxytocin, cloprostenol or saline on Day 0,1 or 2 postovulation. Theriogenology 2003;60:1119-25.

[21] Ginther O, Silva L, Araujo R, Beg M. Temporal associations among pulses of 13 , 14-dihydro-15-keto-PGF2alpha, luteal blood flow, and luteolysis in cattle. Biol Reprod 2007;76:506-13.

[22] King S, Dille E, Marlo T, Roser J, Jones K. Ovarian prolactin activity: evidence of local action and production. Anim Reprod Sci 2010;121:51-3.

[23] Ginther O, Pinaffi F, Silva L, Beg M. Temporal relationships of a pulse of prolactin (PRL) to a pulse of a metabolite of PGF $2 \alpha$ in mares. Theriogenology 2012;77:99-107.

[24] Vanderwall DK, Newcombe JR. Early embryonic loss. In: Pycock J, Samper JC, McKinnon AO, editors. Current therapy in equine reproduction. St. Louis: Saunders Elsevier; 2007. p. 374-83.

[25] Henneke D, Potter G, Kreider J, Yeates B. Relationship between condition score, physical measurements and body fat percentage in mares. Equine Vet J 1983;15:371-2.

[26] Practitioners AAoE. Official guide for determining the age of the horse. Fort Dodge Laboratories; 1981.

[27] Ginther OJ. Ultrasonic imaging and animal reproduction. Madison: Equiservices Publishing; 1995.

[28] Cuervo-Arango J, Newcombe J. Ultrasound characteristics of experimentally induced luteinized unruptured follicles (LUF) and naturally occurring hemorrhagic anovulatory follicles (HAF) in the mare. Theriogenology 2012;77: $514-24$.

[29] Gastal E, Gastal M, Ginther O. The suitability of echotexture characteristics of the follicular wall for identifying the optimal breeding day in mares. Theriogenology 1998;50:1025-38.

[30] Colborn D, Thompson D, Roth T, Capehart J, White K. Responses of cortisol and prolactin to sexual excitement and stress in stallions and geldings. J Anim Sci 1991;69:2556-62.

[31] Ginther O. Reproductive biology of the mare: basic and applied aspects. Cross Plains. Equiservices Publishing; 1992.

[32] Mocklin C, Paccamonti D, Eilts B, Lyle S, Wouters E, Gentry L, et al. Effect of post-ovulatory PGF (2 alpha alpha) or cloprostenol on plasma progesterone concentration in mares. Anim Reprod Sci 2006:220-2.

[33] Holland B, Pinto C. Luteal function and ovulation in mares treated with PGF2 alpha during early and mid-diestrus. Reprod Domest Anim 2008:111.

[34] Rubio C, Pinto C, Holland B, Da Silva B, Layne S, Heaton L, et al. Anti-luteogenic and luteolytic effects of PGF2 $\alpha$ during the post-ovulatory period in mares.
Theriogenology 2008;70:587.

[35] Coffman E, Pinto CRF, Snyder $H$, Leisinger C, Cole K, Whisnant C. Antiluteogenic effects of serial prostaglandin F2 $\alpha$ administration in cycling mares. Theriogenology 2014;82:1241-5.

[36] Troedsson M, Ababneh M, Ohlgren A, Madill S, Vetscher N, Gregas M. Effect of periovulatory prostaglandin F2 $\alpha$ on pregnancy rates and luteal function in the mare. Theriogenology 2001;55:1891-9.

[37] Brendemuehl J. Effect of oxytocin and cloprostenol on luteal formation, function and pregnancy rates in mares. Theriogenology 2002;58:623-6.

[38] Nie GJ, Johnson KE, Wenzel JG, Braden TD. Effect of administering oxytocin or cloprostenol in the periovulatory period on pregnancy outcome and luteal function in mares. Theriogenology 2003;60:1111-8.

[39] Ginther O, Araujo R, Palhao M, Rodrigues B, Beg M. Necessity of sequential pulses of prostaglandin F2alpha for complete physiologic luteolysis in cattle. Biol Reprod 2009;80:641-8.

[40] Nascimento AB, Souza AH, Keskin A, Sartori R, Wiltbank MC. Lack of complete regression of the Day 5 corpus luteum after one or two doses of PGF $2 \alpha$ in nonlactating Holstein cows. Theriogenology 2014;81:389-95.

[41] Meira C, Pessoa VM, Ferreira JCP, Araujo GHM, Gioso MM, Bicudo SD, et al Alternative low doses and routes of administering a prostaglandin F2 $\alpha$ analogue to induce luteolysis in Nelore cows. J Vet Sci 2006;7:387-90.

[42] Ginther O, Beg M. Concentrations of circulating hormones normalized to pulses of a prostaglandin $\mathrm{F} 2 \alpha$ metabolite during spontaneous luteolysis in mares. Theriogenology 2009;72:1111-9.

[43] Baishya N, Cooper M, Hart I, Jackson P, Furr B, Jenkin G, et al. Effects of luteolytic doses of prostaglandin $\mathrm{F} 2 \alpha$ and cloprostenol on concentrations of progesterone, luteinizing hormone, follicle-stimulating hormone, glucose, insulin, growth hormone, thyroxine, prolactin and cortisol in jugular plasma of lactating dairy cows. Br Vet J 1994;150:569-83.

44] Schallenberger E, Schams D, Bullermann B, Walters D. Pulsatile secretion of gonadotrophins, ovarian steroids and ovarian oxytocin during prostaglandininduced regression of the corpus luteum in the cow. J Reprod Fertil 1984;71: 493-501.

[45] Shrestha H, Beg MA, Imam S, Ginther O. Luteal blood flow and concentrations of circulating progesterone and other hormones associated with a simulated pulse of 13, 14-dihydro-15-keto-prostaglandin F2 $\alpha$ in heifers. Reproduction 2010;139:673-83.

[46] King S, Roser J, Jones K. Follicular fluid prolactin and the periovulatory prolactin surge in the mare. J Equine Vet Sci 2008;28:468-72.

[47] Shand N, Irvine C, Turner J, Alexander S. A detailed study of hormonal profiles in mares at luteolysis. J Reprod Fertil 1999:271-9.

[48] Murdoch W, Peterson T, Van Kirk E, Vincent D, Inskeep E. Interactive roles of progesterone, prostaglandins, and collagenase in the ovulatory mechanism of the ewe. Biol Reprod 1986;35:1187-94.

[49] Ginther O, Gastal E, Gastal M, Beg M. Effect of prostaglandin F2 $\alpha$ on ovarian, adrenal, and pituitary hormones and on luteal blood flow in mares. Domest Anim Endocrinol 2007;32:315-28.

[50] Acosta TJ, Miyamoto A. Vascular control of ovarian function: ovulation, corpus luteum formation and regression. Anim Reprod Sci 2004;82:127-40.

[51] Ford S, Weber L, Kennick W, Stormshak F. Response of bovine ovarian arteria smooth muscle to prostaglandinF $\alpha$ and neurotransmitter. J Anim Sci 1977;45: 1091-5.

[52] Hayashi K, Acosta T, Berisha B, Kobayashi S, Ozawa T, Fukuda R, et al. Real time changes in the local angiotensin system and prostaglandin production in the regressing corpus luteum in the cow [abstract]. Biol Reprod 2001:132.

[53] Ohtani M, Kobayashi S, Miyamoto A, Hayashi K, Fukui Y. Real-time relationships between intraluteal and plasma concentrations of endothelin, oxytocin, and progesterone during prostaglandin F2alpha-induced luteolysis in the cow. Biol Reprod 1998;58:103-8.

[54] Boiti C, Zerani M, Zampini D, Gobbetti A. Nitric oxide synthase activity and progesterone release by isolated corpora lutea of rabbits in the early and midluteal phases of pseudopregnancy are modulated differently by prostaglandin E-2 and prostaglandin F-2alpha via adenylate cyclase and phospholipase C. J Endocrinol 2000;164:179-86.

55] Gobbetti A, Boiti C, Canali C, Zerani M. Nitric oxide synthase acutely regulates progesterone production by in vitro cultured rabbit corpora lutea. J Endocrino 1999; 160:275-83.

[56] Tanaka J, Acosta TJ, Berisha B, Tetsuka M, Matsui M, Kobayashi S, et al. Relative changes in mRNA expression of angiopoietins and receptors tie in bovine corpus luteum during estrous cycle and prostaglandin F $2 \alpha$-induced luteolysis: a possible mechanism for the initiation of luteal regression. J Reprod Dev 2004:50:619-26. 